\title{
Transformational Leadership: Lessons in Management for Today
}

\author{
Charles J. Berendt ${ }^{1}$, Andreas Christofi ${ }^{2}$, Krishna M. Kasibhatla ${ }^{3}$, John Malindretos ${ }^{4}$ \& Brian Maruffi ${ }^{5}$ \\ ${ }^{1}$ Graduate School of Business, Touro College, United States \\ ${ }^{2}$ Leon Hess Business School, Monmouth University, United States \\ ${ }^{3}$ School of Business and Economics, North Carolina Agricultural and Technical State University, United States \\ ${ }^{4}$ Cotsakos College of Business, William Paterson University, United States \\ ${ }^{5}$ Syms School of Business, Yeshiva University, United States \\ Correspondence: John Malindretos, Cotsakos College of Business, William Paterson University, United States. \\ E-mail: jnmalindre@optonline.net
}

Received: July 1, 2012

doi:10.5539/ibr.v5n10p227
Accepted: August 16, $2012 \quad$ Online Published: September 7, 2012

URL: http://dx.doi.org/10.5539/ibr.v5n10p227

\begin{abstract}
This paper examines the underappreciated differences between the effectiveness and measurement of current technical advances in business management methods and how aspects of transformational leadership, as exhibited by the prophet Moses, can more broadly and deeply contribute to an organization's success over the long term than these more easily defined procedures. These leadership issues tend to arise most acutely when a company's management comes under severe scrutiny during times of business scandals and related ethical crises. Using Warren Bennis's definition of charismatic leadership as a framework, we show how Moses exhibited the qualities of humility, tenacity, integrity, strength, creativity, and innovation, particularly in the field of succession planning, in completing his mission, transforming the 'organization' he led, and inspiring future generations. The conclusions here are supported not only by biblical passages but also by relevant business, management, and general literature.
\end{abstract}

Keywords: leadership, management, scandal, motivation, innovation, creativity, succession planning

\section{Introduction}

Diverse reasons and arguments have been offered to explain the business scandals of the past few years. It is logical that, when major moral or ethical lapses occur in society, people attempt to understand what the cause or causes were. We also tend to make comparisons with past times in an effort to know whether we are improving or degrading morally.

Several theorists argue that these recent business disasters are largely due to poor management. These theorists promote the idea that ineffective executives managing organizations attempt to disguise mismanagement by unethical and even criminal acts and then exacerbate the damage with deception. However, it is hard to explain the dramatic advances in gross domestic product and in productivity per employee that are documented and objectively measured today by offering ineffective management as the root cause.

According to the evidence, today's CEOs probably work harder, are better educated and better prepared than ever before, and spend billions of dollars to train and develop managers annually. In addition, unique management systems and costly, sophisticated scientific techniques such as Total Quality Management, Six Sigma, ISO 9000/9001, and, in software development and engineering, the Capability Maturity Model, have been implemented and demonstrably improved the effectiveness and the efficiency of the management function. What is it then that will give us a proper perspective on these costly and embarrassing failures on the part of so many top business leaders?

Some people have made a strong case that it is a lack of morality in society as a whole. The current crop of managers and executives, being part of society themselves, are just prime examples of an atmosphere of amorality and situational ethics rampant throughout society, or so these persons claim. However, how does that hypothesis stand up when we compare our contemporary miscreants with those great and famous industrialists of the late $19^{\text {th }}$ and early $20^{\text {th }}$ centuries, back in the Gilded Age or robber baron era? 
Today's CEOs and top managers actually have more numerous and far more effective constraints on their abilities to take advantage of the unsuspecting public than their predecessors ever did. They must answer to governmental rules and regulations, intense media scrutiny, and a public - comprising financial professionals, average investors, and the general public - that is better educated and more informed than ever before. (Obviously, enforcement of these laws and standards is an entire issue beyond the scope of this paper.) Furthermore, a brief historical overview of the muckraking era in American history would reveal that John D. Rockefeller, Andrew Carnegie, and J.P. Morgan's ethical standards regarding their customers, employees, or stockholders would be far more abusive than those of today's CEOs (or former CEOs) making negative headlines.

This is why we need Moses today more than ever. Or we might more plaintively ask, "Moses, where are you when we need you?"

What is necessary in order for any organization to be successful in the long run is good management and good leadership; most everything else springs forth from these two items. The two are often confused as simply being two sides of the same coin. It is assumed that someone who is put in charge of a company or a major division within one would automatically be the manager and leader of it and be seen as such by his or her subordinates. But it is also true that, despite specific job titles, not all managers are really leaders in the truest sense of the word and not all leaders are managers. The problem for us is that this distinction is not always clear.

\section{Aspects of Leadership}

Warren Bennis, of the University of Southern California, has defined the difference in these ways:

The manager administers; the leader innovates.

The manager maintains; the leader develops.

The manager focuses on systems and structures; the leader focuses on people.

The manager has a short-range view; the leader has a long-range perspective.

The manager has his or her eye on the bottom line; the leader has his or her eye on the horizon.

The manager imitates; the leader originates.

Bennis (2002) has also written that there are seven managerial attributes indispensible to true leadership, some of which include: a track record of results; the communications skills to motivate and delegate; judgment exercised in decision making; character (our most intensely personal qualities); and taste, defined as "the ability to identify and cultivate talent," especially developing the successors and heirs apparent in the organization over a period of time and not through a one-time event. (We will return to the issues of taste and cultivating successors a bit later.). For a manager also to be a leader he or she must be a coach (and sometimes be the organizational prophet or visionary) as well as someone fulfilling the somewhat more mundane and easily defined duties of hiring, budgeting, conducting performance appraisals, and so on. The decisions made by this manager/leader must nurture the collective spirit of the organization for the good of its long-term health.

Perhaps what is lacking in many of our so-called leaders today, not only in business but in the fields of politics, entertainment, religion, or any other human endeavor, is a particular kind of leadership. This is the kind that it appears, from all scripture and tradition, Moses possessed and what we call "charismatic leadership." What is meant by this term, also called "transformational" at times? It is based on personal values, beliefs, and qualities in combination with the ability to elevate the interests, awareness, and acceptance of the group and to stir followers to look beyond their own interests. In fact, no less a personage than Sigmund Freud, writing of the qualities of great men in general in his final book, Moses and Monotheism (1939/1961), said that "the great man influences his contemporaries in two ways: through his personality and through the idea for which he stands." For us, Moses stands at a particular nexus of history, religious faith, legend, and literature. The task here is to highlight some aspects of his charismatic or transformational leadership at relevant places in the Hebrew Bible, only hastening to add that, although Moses' leadership may superficially appear to have been a failure, as most adults liberated from Egypt in the Book of Exodus, including himself, did not live to see the Promised Land, the children of Israel collectively were changed by Moses' examples and innovations from twelve confederated tribes into one nation.

\section{Humility}

The first leadership attribute of Moses we can point out is his respect for his employer, namely, the Lord Who has chosen and charged him with his monumental task. This respect manifests itself most clearly as humility above all else. For example, Moses very famously asks, “Who am I, that I should go unto Pharaoh?” (Exodus 
3:11) and adds in the next chapter "I am not a man of words . . I I am slow of speech, and of a slow tongue" (Exodus 4:10). Despite his own aristocratic upbringing in Egypt and his firsthand knowledge of the Israelites' suffering, Moses did not see the leadership qualities latent within himself that the Lord did in making His request nor did Moses distinguish between the quality of the words he must speak with their speed and quantity. Moses humbly and reluctantly accepted the job offer only after Aaron was offered as an intermediary to the people after which he immediately asked permission from his Midianite father-in-law to return to Egypt.

We, as readers of the Exodus narrative, can also see why Moses might have been humble after he wondered aloud how Pharaoh could listen to someone like himself with "uncircumcised lips" (Exodus 6:12, 30). In between the two times Moses uses this phrase, we are given a brief genealogy of the Levite tribe which not only serves to show Moses and Aaron coming forth out of the children of Israel but also states that they themselves were the products of a nephew/aunt marriage that would only later be condemned as unlawful (see Leviticus 18:12 and 20:19). In other words, as has been pointed out by the scientist and scholar Yeshayahu Leibowitz (1990/2002), Moses knew that he could neither claim for himself a noble birth nor be haughty over the other Israelites no matter how demanding his entreaties to follow the Lord's commands. (Leibowitz even concludes, "In other words, remember who you are. And this is a warning to the leadership in all generations and all eras.”) In the Bible, we are also told that "the man Moses was very meek, above all" when the Lord says that Moses speaks to Him face to face (Numbers 12:3,8), and Moses still considered himself only a beginner in glimpsing God's greatness as late as Deuteronomy 3:24.

In the business world, Moses' style of leadership is more than reminiscent of the "servant as leader" model espoused by writers such as Robert K. Greenleaf (1977). In this scenario, servant leaders display humility - as distinct from being overly modest, quiet, or self-deprecating - by considering their own needs, whether professional or personal, as secondary to the needs of their followers and the organization which they are leading. This is a significant difference from other leadership styles, including the "democratic" or participative style, in that the servant leader's desire to serve the organization in better ways stems from neither an innate desire for power nor a belief that he or she is the best one to lead. Servant leadership contains a number of distinctive characteristics and abilities itself, including being a good listener (such as Moses was with Jethro), being persuasive and aware of one's surroundings, and displaying both empathy toward and stewardship over others in the organization. These qualities are especially important to the servant leader in that they help him or her better understand followers' needs, aspirations, and interests and become able to help the entire organization achieve its goals while also maintaining enough control so that followers can function successfully without undue pressure or resentment. Servant leaders see themselves as entrusted with managing the human assets of an organization and thus feel responsible for helping all members maximize their potential.

\section{Tenacity and Perseverance}

Moses also displayed a respect for the "employees" of his "corporation” through his single-mindedness, tenacity, and perseverance - a passion for excellence in helping others achieve more for themselves now that they have laws and values handed down from God to live up to - balanced with compassion for the downtrodden and an open-mindedness to innovation. In the business press, we can reference Peters and Waterman's phrase "loose-tight properties" from In Search of Excellence (1982/1984), "where there is dedication to the central values of the company combined with tolerance for all employees who accept those values . . . in essence the co-existence of firm central direction and maximum individual autonomy."

For example, Moses' greatest examples of tenacity and endurance are undoubtedly his repeated entreaties to Pharaoh to release the Israelites during the time of the ten plagues in Egypt (beginning at Exodus 7:14). He displays an increasing self-confidence as the plagues set in, maturing from believing at first that Pharaoh would free the Israelites after the early plague of frogs (Exodus 8:5,6) to his rejection of Pharaoh's offer of letting the Israelites give sacrifice to the Lord in Egypt during the plague of flies (Exodus 8:22), to his informing Pharaoh that he knows that he will not release the Israelites after the plague of hail (Exodus 9:30), and then to Moses' additional demand that the Israelites' cattle be freed for possible future sacrifice after the plague of darkness (Exodus 10:26). By the onset of the final plague, Moses was almost uniformly seen in Egypt as a leader of the Israelites (see Exodus 11:3: "the man Moses was very great in the land of Egypt, in the sight of Pharaoh's servants, and in the sight of the people" - meaning all the common people in Egypt and not merely the Israelites); the tip-off to readers that his tenacity has resulted in his increasing stature as a true leader is that instead of the often-used formulaic phrase "And the Lord said unto Moses" preceding a description of the tenth plague, we have the more active and direct words "And Moses said: 'Thus saith the Lord'” in the announcement of the deaths of the first-born (compare Exodus 11:1 and 11:4). 
Ironically, Moses' other great challenge in perseverance came in dealing with his fellow Israelite veterans of the Exodus in the intermittent challenges to his leadership, questioning of the overall mission, and repeated requests to return to Egypt. This was true at the famous parting of the Red Sea (or Sea of Reeds) before the Egyptian army at Exodus 14:11-14, when they were asking for water in the encampments at Shur, Sin, and Rephidim in the Book of Exodus and at Zin, Edom, and Kadesh in the Book of Numbers (they also asked for meat at Taberah and complained of the boredom of eating manna at Edom), and in handling the uprisings started by Korah and Dathan in Numbers 16 and 17 and the widespread harlotry and idolatry mentioned early in Numbers 25. (Moses also foretells the Israelites' recalcitrant behavior in Deuteronomy 31:27-29)

In fact, Moses was so intent on completing his mission and in raising up his compatriots that on three occasions he stayed their destruction from divine wrath. Moses instructed Aaron in Numbers 17 to appease the Lord by atonement so as to limit the effects of a deadly plague sent by God meant to consume all the congregation of the children of Israel and Moses interceded and well-nigh chastised God on their behalf twice when he was personally offered the chance to be the founder of a new, and perhaps less rebellious, nation as God had wanted to destroy them after the incidents of the golden calf and the rebellion upon hearing the negative report of the spies coming back from Canaan (see Exodus 32 and Numbers 14, respectively, as well as Deuteronomy 32:26-27). These episodes took place with both the adult generation Moses led out of Egypt and the one that grew up in the desert with him as its leader. Moses displays strong elements of servant leadership in these episodes by being more concerned for the welfare of his people, and thus interceding on their behalf, than in raising his own personal status.

\section{Integrity}

Another leadership attribute of Moses is his integrity. Not only did he personally sacrifice by forsaking a privileged life in Egypt and by declining offers to become a "new Abraham," but he was able to see the Israelite suffering despite never having been in bondage himself. His integrity and character are evidenced by his help given to one of his fellow Hebrews being beaten by an Egyptian in Exodus 2:11 and then soon after helping the Midianite women water their flocks without interference from local shepherds. The ironies inherent in these two acts of generosity are that in both cases he is seen publicly as an Egyptian helping a member of an unpopular or downtrodden group and that he will soon after, and probably for a significant period of his life, become one of these shepherds himself. Thus Moses is providing a leadership example of (literally) being a good shepherd long before he is called upon to lead the Israelites. Moses' absence of a "slave mentality" also clearly puts him in sharp contrast with the vast majority of the Israelites he helped liberate and, per Miles (1995), is a huge influence upon his leadership role in the founding of ethical monotheism through the laws and statutes he handed down.

\section{Creativity}

A fourth attribute we can ascribe to Moses is his creativity in implementing innovations among the Israelites, whether ordered to by the Lord or suggested by other persons. The most striking among these innovations from a business perspective is the delegation of authority given at Moses' command toward developing and cultivating the next generation of leaders within the organization. Moses grew up in a royal Egyptian court ruled by an absolute monarch assisted only by magicians where he could have succeeded to power himself some day; among the Israelites, Moses carved out a separate sphere of influence for his brother Aaron and Aaron's sons by the establishment of the priesthood, a "realm of power distinct from his own ... with all the rituals and sacrifices that went along with it" (Brown \& Padwa, 1999/2000) and by his use of Aaron as a spokesman to the Israelites beginning at Exodus 4:30 and to Pharaoh at Exodus 7:2. These priestly rituals replaced the ill-defined "elders" of Exodus 4:29 and the "officers of the children of Israel" mentioned in Exodus 5:14 as community leaders. Also note that worship among the people (e.g., Exodus 4:31) likewise predated the priesthood, but without any identified leaders. Once the Israelites are freed from Egyptian bondage, Moses implemented the initial altar sacrifices and wrote the mostly civil law handed down by God after the Ten Commandments called the Book of the Covenant. But, at God's command, he also delegated the priesthood to Aaron's family and relayed the Lord's instructions for building a Holy Ark and a tent of meeting, including the naming of expert craftspeople such as Bezalel and Oholiab and all "wise-hearted" women who could "spin with their hands" (see Exodus 25, 28, and 35 for details).

Moses also implemented the institution of the Sabbath even before the commandment to remember it was given at Mount Sinai (see Exodus 16:23-30) and the first annual commemoration of the Passover holiday in Numbers 9:1-5 as two other major innovations in the religious life of his people. Most interestingly, he followed his father-in-law Jethro's advice in delegating levels of judgeships for deciding smaller cases affecting only "thousands, hundreds, fifties, and tens" (see Exodus 18:21) so as to save time and energy, even though our 
recognized basis for what they could judge others by, the Torah, had yet to be given at Sinai. Moses also helped to establish and implement more equitable laws of inheritance by bringing the Lord's attention to the case of the daughters of Zelophehad in Numbers 27.

In grooming a successor as CEO, however, Moses was particularly innovative in choosing neither his own sons Gershom or Eliezer nor any member of Aaron's family nor any of the "elders" already in place at the time of the Exodus but rather in choosing to cultivate talent and leadership within Joshua. The references to him in the text grow steadily in importance as Moses must have seen leadership qualities in him develop over an extended period of time, beginning with the battle against the Amalekites in Exodus 17:9, the mention next of "Joshua his [Moses'] minister" (Exodus 24:13), his inclusion among the twelve spies sent into Canaan (Numbers 13:1-16), his preparation by Moses as the next shepherd of the children of Israel in Numbers 27:15-23, and his being named along with Aaron's son Eleazar and the tribal representatives to take possession of the Promised Land and divide its inheritance (Numbers 34:16-29), all of which leads to his being charged by Moses, with all the Israelites present, as his successor in Deuteronomy 31:7-8. To put it succinctly, "[i]t has been argued that Moses's [sic] greatest and most independent act of leadership was in recognizing the importance of finding, selecting, and grooming his own replacement” (Pava, 2003).

This emphasis on cultivating leadership within the organization is perhaps borne out by one study (Brawer, 1998) at Cornell University's business school, where Fortune 1000 senior executives surveyed were "increasingly concerned with soft skills, such as how to nurture and develop employees . . . and develop leadership.” Furthermore, being able to step aside at the right time and not overstay one's welcome is a further check on arrogance and complacency and "the best way to bequeath a living legacy and keep [one's] reputation at its zenith" (Koch, 1999).

\section{Mental and Physical Strength}

Moses also possessed the qualities or attributes of mental and physical competence that enabled him to do his job for so long and so well. Moses first had the physical strength to smite the Egyptian who was striking a Hebrew, cross the desert to Midian, and then drive away the shepherds harassing Jethro's daughters. At Mount Sinai or Horeb, he ascended the mountain for 40 days for the first set of tablets and then another 40 days, but this time explicitly without any food or water, for the second set of tablets upon which he carved the Ten Commandments himself, while also having the strength and physical endurance to break the first pair of tablets and later grind the golden calf down to powder (see Exodus 24, 32, and 34). Most impressively, perhaps, Moses personally constructed the tabernacle within which he could meet the Lord after the materials had been fashioned by other dedicated Israelites (Exodus 40:17-33). Finally, Moses, who had stated early in the narrative that he was slow of tongue, concluded his life with several long and eloquent speeches on his $120^{\text {th }}$ birthday taking up most of the Book of Deuteronomy - an example of how his leadership was reinforcing his communication and motivational skills right up to the very end. As the text states, "his eye was not dim, nor his natural force abated" (Deuteronomy 34:7).

\section{Conclusion}

As we have seen, Moses fits Warren Bennis's definition of the charismatic or transformational leader: developing people; innovating and originating; keeping a long-term horizon in view; elevating the members of the group beyond their own immediate interests (at least temporarily); being as physically and mentally tough or compassionate as needs dictate; and having a strong track record of accomplishment from the Exodus and Sinai. The end product of the transformation is a nation now hardened through a generation or more of collective triumphs and setbacks, ready to fulfill its destiny in the Promised Land and develop the next set of leaders beyond Joshua, in short, having achieved its freedom with a certain measure of human dignity through a difficult process and journey rather than through one revelation or miracle. Recall that at Moses' birth in the Exodus narrative, the fledgling nation was under bondage, passively accepting all manner of food provided for them (as its members were fond of recalling on numerous occasions). However, freedom itself, like the taste or judgment required in developing true leaders, "is an activity of perception and judgment based on a great range of particular acts and experiences. Whatever fosters mere passivity and submission is the enemy of this vital activity" (McLuhan, 1951/1967).

Also note in comparison that the Book of Exodus actually begins before the Israelites' bondage in Egypt with a summation of the passage of time almost sublime in its brevity - "And Joseph died, and all his brethren, and all that generation" (Exodus 1:6) - but with no mention of any Hebrew successor or subsequently of Joseph by the Israelites themselves. (One can sense that while the new pharaoh "knew not Joseph" (Exodus 1:8), the Israelites' own institutional memory in this regard may have been only marginally better.) Once Moses dies, however, we 
are told not only that Joshua is his hand-chosen successor but that "there hath not arisen a prophet since in Israel like unto Moses” (Deuteronomy 34:9-10).

Moses would not have wanted to participate in, perpetuate, or emulate a system whereby he merely substituted himself or his successors for the monarch and would-be deity from whom they escaped. Our hope is that business leaders can use some of Moses' effective leadership traits highlighted here to lead and transform their companies and preserve for future generations what they have fought for and won.

\section{References}

Bennis, W. (2002). The Leadership Advantage. In F. Hesselbein \& R. Johnston (Eds.), On Mission and Leadership: A Leader to Leader Guide (pp. 7-18). San Francisco: Jossey-Bass.

Brawer, R. A. (1998). Fictions of Business: Insights on Management from Great Literature (p. 167). New York: John Wiley \& Sons.

Brown, D., \& Padwa, L. (2000). Moses on Management: 50 Leadership Lessons from the Greatest Manager of All Time (p. 52). New York: Pocket Books.

Freud, S. (1961). Moses and Monotheism (p. 139). (K. Jones, Trans.). New York: Vintage Books.

Greenleaf, R. K. (1977). Servant Leadership: A Journey into the Nature of Legitimate Power and Greatness. New York: Paulist Press.

Koch, R. (1999). Moses on Leadership: Or Why Everyone is a Leader (p. 8). Oxford, U.K.: Capstone Publishing Limited.

Leibowitz, Y. (2002). Accepting the Yoke of Heaven: Commentary on the Weekly Torah Portion (pp. 63-64). (S. Himelstein, Ed. and Trans.). New York: Urim Publications.

McLuhan, H. M. (1967). The Mechanical Bride: Folklore of Industrial Man (p. 22). Boston: Beacon Press.

Miles, J. (1995). God: A Biography (pp. 110-111). New York: Alfred A. Knopf.

Pava, M. L. (2003). Leading With Meaning: Using Covenantal Leadership to Build a Better Organization (p.153). New York: Palgrave Macmillan.

Peters, T. J., \& Waterman, Jr., R. H. (1984). In Search of Excellence: Lessons from America's Best-Run Companies (p. $i, 318)$. New York: Warner Books. 